\title{
Soil Properties under Different Land Use Systems in Karimganj District of Assam, India
}

\author{
M. R. Choudhury ${ }^{1 *}$, S. Dutta ${ }^{2}$ and D. Bhattacharyya ${ }^{2}$ \\ ${ }^{1}$ Regional Agricultural Research Station, Assam Agricultural University, \\ Karimganj, Assam, India \\ ${ }^{2}$ Department of Soil Science, Assam Agricultural University, Jorhat, Assam, India \\ *Corresponding author
}

\section{A B S T R A C T}

\section{Keywords}

Land use systems,

Vegetable-

vegetable, Pulse-

oilseed,

Uncultivated, Total organic carbon

Article Info

Accepted:

05 February 2020

Available Online:

10 March 2020
Geo-referenced composite soil samples were collected from twelve different land use systems (LUS) of the Karimganj district of Assam. The results revealed a wide textural variation ranging from silt loam to clayey in the studied soils. Bulk density was significantly higher $\left(1.48 \mathrm{Mg} \mathrm{m}^{-3}\right)$ in uncultivated LUS and lowest $\left(1.20 \mathrm{Mg} \mathrm{m}^{-3}\right)$ recorded in forest. Porosity of soils ranged from $39.9 \%$ to $52.1 \%$. pH of the soils was found to be very strongly to moderately acidic (4.81-5.78) where tea soils was recorded for significantly lowest value of $\mathrm{pH}$ (4.81). The organic carbon of soils was found medium to high in all LUS. Similar observation was recorded in total organic carbon. CEC of the soils ranged from 7.8 to $10.8 \mathrm{cmol}(\mathrm{p}+) \mathrm{kg}^{-1}$ and found to be mostly regulated by clay fraction of the soils. The percent base saturation of the soils in most of the LUS varied from 30 to $40 \%$.

\section{Introduction}

Soil, the source of infinite life is the most vital and precious natural resource, and not renewable in short time. Soil fertility refers to the ability of a soil to sustain agricultural plant growth, and result with consistent yields of high quality. Soil fertility is a dynamic natural property and it can change under the influence of natural and human induced factors. Parent material, climate, topographical conditions, natural vegetation are the natural factors affecting the soil fertility to a great extent. Among the anthropogenic factors, nutrient management practice is one of the most important factors affecting the soil fertility. Besides the natural factors and nutrient management practices, land use pattern also plays a vital role in governing the nutrient dynamics and fertility of soils (Chavan et al., 1995). Land use system determines the type of vegetation and the soil management practices which in turn affect the processes of erosion, oxidation, mineralization and leaching. 
According to Wang et al., (2001) climate and geological history are the two important factors affecting soil properties on regional and continental scales while, land use may be the dominant factor of soil properties under small catchment scale.

Land use system affect the distribution and supply of soil nutrients by directly altering soil properties and influencing biological transformations in rooting zone. Hence, soil properties are continuously influenced by land uses with profound influence on its productivity and sustainability. Therefore, knowledge on the impact of land uses on soil property has immense importance for sustainable agricultural production and soil health maintenance. Numerous studies on the impact of land use systems on properties and fertility status of soils of both abroad and the country is appeared in the scientific literature. However, very little work has been done in this direction in Assam and more particularly in soils of Barak valley region.

Barak valley is situated between Longitude $92^{\circ} 15^{\prime}$ and $93^{\circ} 15^{\prime}$ East and Latitude $24^{\circ} 8^{\prime}$ and $25^{\circ} 8^{\prime}$ North covering an area of $6922 \mathrm{sq}$ $\mathrm{km}$. The Barak Valley region, which forms the southern part of the state of Assam, is comparatively smaller in size than the Brahmaputra valley. The valley is characterized by undulating topography. The hills and hillocks, locally known as tillas predominate the land surface. Karimganj district covers an area of 1839 Sq. Kms., and is situated between $24^{\circ} \mathrm{N}$ latitude and $92^{\circ} \mathrm{E}$ longitude. It is on the left Bank of the river Kushiara and is extreme southern periphery of Assam. The district is surrounded by Bangladesh and Cachar district of Assam in the north, Mizoram in the south, Bangladesh and Tripura in the west and Hailakandi district of Assam in the east. The district covers an area of 1839 Sq. Kms. which comes under Agro-Eco Sub Region, AESR 15.3 Q8A9.
Various land use systems viz. rice based, arable crop based and plantation crop based etc. are commonly prevalent in the district but little information is available on soil properties in general and impact of land use systems on soil properties in particular, the present study was thus undertaken.

\section{Materials and Methods}

Ten geo-referenced composite surface $(0-$ $0.25 \mathrm{~m}$ ) soil samples from each of the dominant land use systems e.g., rice-fallow, rice-pulse, rice-oilseed, rice-vegetable, vegetable-vegetable, pulse-oilseed, uncultivated, tea, rubber, arecanut, jhum (abandoned) and forest land use systems thereby totaling one hundred twenty soil samples were collected from twelve land use systems of Karimganj district in Assam were studied. The collected soil samples were air dried in shade, grinded, mixed well and passed through a $2 \mathrm{~mm}$ sieve to remove stones, roots and large organic residues and then kept in polythene bags with proper labelling for subsequent laboratory analysis. Mechanical analysis of soil was done by International Pipette Method (Piper, 1966). Samples were analysed for bulk density by Clod method (Black, 1965), Particle density by Pycnometer method (Black, 1965), pH (1: 2.5 soil/water ratio), organic carbon (Walkley and Black, 1934), total organic carbon (Schumacher, 2002), electrical conductivity by Conductivity Bridge method. Soil samples were also analysed for exchangeable $\mathrm{Al}$ (McLean, 1965), exchangeable cations by leaching with neutral normal $\mathrm{NH}_{4} \mathrm{OAc}$ (Barrows and Simpson, 1962), cation exchange capacity by distillation method.

Duncan's Multiple Range Test (DMRT) has been done for all the LUS to evaluate the variation of parameters among these twelve different land use systems of the district. 


\section{Results and Discussion}

The physico-chemical properties of the soils under all the land use systems in Karimganj district of Assam were presented in Table 1. Clay particle showed significant variation with a range of $23.6 \%$ in rubber to $36.4 \%$ in ricevegetable land use system. It was observed that clay content was higher in field crop based LUS than those of tree based LUS. The bulk density of the soils under these twelve land use systems varied significantly from $1.20 \mathrm{Mg} \mathrm{m}^{-3}$ in forest to $1.48 \mathrm{Mg} \mathrm{m}^{-3}$ in uncultivated LUS (Table 1). The higher mean bulk density in the uncultivated land might be due to the soil compaction, lighter texture and degradation of organic matter (Donis and Assefa, 2017). Porosity of the soils ranged significantly from $39.9 \%$ in abandoned jhum land to $52.1 \%$ in rubber plantation (Table 1). The lowest porosity (39.9\%) in abandoned jhum LUS (Table 1) could be attributed to the fact that burning of forest might have degraded the soil organic matter resulting soil compaction leading to highest bulk density of the soil. This was supported by the existence of significant negative correlation $(\mathrm{r}=$ $\left.0.758^{* *}\right)$ between porosity and bulk density (Table 2; Mhawish, 2015).

Soil $\mathrm{pH}$ measured from the fields of Karimganj district under different land use systems were found to be very strongly to moderately acidic and was significantly affected by the land use systems. It was the highest (5.78) in arecanut LUS (Table 1) which might be due to the lower organic matter content as well as absence of the effect of any acid forming fertilizers. Significant and negative relation between soil $\mathrm{pH} \&$ organic carbon as well as with total organic carbon was observed in the present study (Table 2). In general, the organic carbon content of soils under all the land use systems was medium to high. The organic carbon and total organic carbon content in all the soils under different land use systems ranged from $0.64 \%$ in ricefallow \& rice-oilseed LUS to $1.42 \%$ in forest land use and $0.85 \%$ in rice-oilseed to $1.98 \%$ in forest respectively (Table 1 ). The highest OC and TOC content in forest land could be the result of addition of organic matter by decay of leaves and the lowest OC \& TOC in cultivated lands like rice-fallow, rice-oilseed could be due to continuous cultivation that aggravated OC oxidation (Dawit et al., 2002). The significantly highest value [10.8 cmol $\left.(p+) \mathrm{kg}^{-1}\right]$ of CEC was noticed in forest LUS might be due to the high quantity of organic matter content in forest soil (Table 1). The per cent base saturation of the soils in all land use system varied from $15.60 \%$ in tea plantation to $45.96 \%$ in arecanut land use system (Table 1). Significantly highest and lowest PBS in arecanut and tea LUS could be attributed to the highest and lowest $\mathrm{pH}$ in respective land use systems that was supported by the positive significant correlation $(\mathrm{r}=$ $0.458 * *$, Table 2) between PBS \& pH (Dutta and Zaman, 2013; Dutta et al., 2017).

The present study revealed a picture on the influence of different land use systems on the physico-chemical properties of the soils of Karimganj district of Assam. It has been observed that forest and abandoned jhum land exhibited better status in most of the soil parameters than the other land use system. The mean bulk density values of the studied soils were found higher in uncultivated LUS indicated more soil compaction in uncultivated LUS resulting unfavourable soil condition. Moreover, Percent Base Saturation was also significantly low in soils under tea, rubber and uncultivated LUS. Considering the forest land as benchmark, the inferiority of soils under agricultural activity is visible in the present investigation. Thus, initiation of judicious and location specific soil management practices becomes an important step in order to maintain the soil health in a sustainable basis. 
Table.1 Distinguished physico-chemical properties of soils under different land use systems in Karimganj district of Assam

\begin{tabular}{|c|c|c|c|c|c|c|c|c|}
\hline Land Use Systems & $\begin{array}{l}\text { Clay } \\
(\%)\end{array}$ & $\begin{array}{l}\text { Bulk Density } \\
\quad\left(\mathrm{Mg} \mathrm{m}^{-3}\right)\end{array}$ & $\begin{array}{c}\text { Porosity } \\
(\%)\end{array}$ & $\mathbf{p H}$ & $\mathrm{OC}(\%)$ & TOC (\%) & $\begin{array}{c}\text { CEC } \\
{\left[\operatorname{cmol}(\mathbf{p}+) \mathrm{kg}^{-1}\right]}\end{array}$ & PBS (\%) \\
\hline Rice-fallow & $36.1^{\mathrm{a}}$ & $1.24^{\mathrm{de}}$ & $46.6^{\mathrm{bcd}}$ & $5.33^{\mathrm{bc}}$ & $0.64^{\mathrm{e}}$ & $0.87^{\mathrm{e}}$ & $10.3^{\mathrm{ab}}$ & $34.08^{c}$ \\
\hline Rice-pulse & $36.3^{\mathrm{a}}$ & $1.32^{\mathrm{bc}}$ & $45.3^{\mathrm{d}}$ & $5.71^{\mathrm{a}}$ & $0.69^{\mathrm{de}}$ & $0.93^{\mathrm{e}}$ & $9.9^{\mathrm{bc}}$ & $39.28^{\mathrm{b}}$ \\
\hline Rice-oilseed & $35.3^{\mathrm{ab}}$ & $1.24^{\mathrm{de}}$ & $49.0^{\mathrm{abc}}$ & $5.67^{\mathrm{a}}$ & $0.64^{\mathrm{e}}$ & $0.85^{\mathrm{e}}$ & $9.8^{\mathrm{bc}}$ & $40.22^{b}$ \\
\hline Rice-vegetable & $36.4^{\mathrm{a}}$ & $1.22^{\mathrm{de}}$ & $49.2^{\mathrm{abc}}$ & $5.53^{\mathrm{ab}}$ & $0.80^{\mathrm{d}}$ & $1.11^{\mathrm{d}}$ & $10.6^{\mathrm{ab}}$ & $32.03^{\mathrm{c}}$ \\
\hline Vegetable-vegetable & $33.3^{\mathrm{abc}}$ & $1.28^{\mathrm{cd}}$ & $49.2^{\mathrm{abc}}$ & $5.53^{\mathrm{ab}}$ & $0.72^{\text {de }}$ & $1.01^{\mathrm{de}}$ & $9.0^{c}$ & $35.61^{\mathrm{c}}$ \\
\hline Pulse-oilseed & $31.8^{\mathrm{bcd}}$ & $1.31^{\mathrm{bc}}$ & $49.8^{\mathrm{ab}}$ & $5.38^{\mathrm{bc}}$ & $0.75^{\mathrm{de}}$ & $1.02^{\mathrm{de}}$ & $9.8^{\mathrm{bc}}$ & $34.70^{\mathrm{c}}$ \\
\hline Uncultivated & $29.4^{\mathrm{cd}}$ & $1.48^{\mathrm{a}}$ & $41.3^{\mathrm{e}}$ & $5.72^{\mathrm{a}}$ & $0.69^{\text {de }}$ & $0.94^{\text {de }}$ & $9.7^{\mathrm{bc}}$ & $28.29^{d}$ \\
\hline Tea & $30.6^{\mathrm{cd}}$ & $1.24^{\mathrm{de}}$ & $51.4^{\mathrm{a}}$ & $4.81^{\mathrm{e}}$ & $1.22^{\mathrm{b}}$ & $1.70^{\mathrm{b}}$ & $7.8^{\mathrm{d}}$ & $15.60^{\mathrm{e}}$ \\
\hline Rubber & $23.6^{\mathrm{f}}$ & $1.24^{\mathrm{de}}$ & $52.1^{\mathrm{a}}$ & $5.11^{\mathrm{cd}}$ & $1.02^{\mathrm{c}}$ & $1.41^{\mathrm{c}}$ & $8.1^{\mathrm{d}}$ & $18.44^{\mathrm{e}}$ \\
\hline Arecanut & $28.2^{\text {de }}$ & $1.36^{\mathrm{b}}$ & $48.8^{\mathrm{abcd}}$ & $5.78^{\mathrm{a}}$ & $0.70^{\text {de }}$ & $0.98^{\mathrm{de}}$ & $9.2^{\mathrm{c}}$ & $45.96^{\mathrm{a}}$ \\
\hline Abandoned jhum & $30.3^{\mathrm{cd}}$ & $1.36^{\mathrm{b}}$ & $39.9^{\mathrm{e}}$ & $4.99^{\mathrm{de}}$ & $1.29^{\mathrm{b}}$ & $1.80^{\mathrm{b}}$ & $9.8^{\mathrm{bc}}$ & $32.81^{\mathrm{c}}$ \\
\hline Forest & $24.8^{\mathrm{ef}}$ & $1.20^{\mathrm{e}}$ & $45.8^{\mathrm{cd}}$ & $4.91^{\mathrm{de}}$ & $1.42^{\mathrm{a}}$ & $1.98^{\mathrm{a}}$ & $10.8^{\mathrm{a}}$ & $40.95^{\mathrm{b}}$ \\
\hline $\mathbf{L S D}_{(0.05)}$ & 3.9 & 0.056 & 3.283 & 0.262 & 0.112 & 0.156 & 0.845 & 3.593 \\
\hline $\operatorname{SEm}( \pm)$ & 1.39 & 0.02 & 1.17 & 0.093 & 0.04 & 0.056 & 0.301 & 1.28 \\
\hline CV (\%) & 14.03 & 5.07 & 7.81 & 5.51 & 14.51 & 14.48 & 9.96 & 12.21 \\
\hline
\end{tabular}

Means followed by the same letter in a column are not significantly different at 5\% level of significance as determined by DMRT 
Table.2 Correlation coefficients (r) among physico-chemical properties under different land use systems in Karimganj district of Assam

\begin{tabular}{|c|c|c|c|c|c|c|c|c|c|c|c|}
\hline & Sand & Silt & Clay & BD & Porosity & pH & OC & TOC & TEC & CEC & PBS \\
\hline Sand & 1 & & & & & & & & & & \\
\hline Silt & $-0.896 * *$ & 1 & & & & & & & & & \\
\hline Clay & -0.154 & $-0.300 * *$ & 1 & & & & & & & & \\
\hline BD & $0.590 * *$ & $-0.389 * *$ & $-0.401 * *$ & 1 & & & & & & & \\
\hline Porosity & $-0.345^{* *}$ & 0.154 & $0.400 * *$ & $-0.758 * *$ & 1 & & & & & & \\
\hline pH & $0.245^{*}$ & $-0.270 * *$ & 0.075 & $0.375^{* *}$ & -0.194 & 1 & & & & & \\
\hline OC & -0.016 & 0.145 & $-0.288 * *$ & $-0.253 *$ & 0.004 & $-0.748 * *$ & 1 & & & & \\
\hline TOC & -0.012 & 0.141 & $-0.289 * *$ & $-0.253 *$ & 0.009 & $-0.749 * *$ & $0.999 * *$ & 1 & & & \\
\hline TEC & -0.006 & -0.112 & $0.264 * *$ & -0.068 & -0.130 & $0.353 * *$ & -0.154 & -0.160 & 1 & & \\
\hline CEC & -0.192 & -0.0008 & $0.415^{* *}$ & $-0.222 *$ & -0.042 & 0.029 & 0.037 & 0.030 & $0.633 * *$ & 1 & \\
\hline PBS & 0.116 & -0.178 & 0.148 & 0.077 & -0.181 & $0.458 * *$ & $-0.261 * *$ & $-0.264 * *$ & $0.923 * *$ & $0.306 * *$ & 1 \\
\hline
\end{tabular}

*Significant at 5\% level of significance

** Significant at $1 \%$ level of significance 


\section{References}

Barrows, H. L. and Simpson, E. C. (1962). An EDTA method for the direct routine determination of calcium and magnesium in soils and plant tissue. Soil Sci. Soc. Am. Proc. 26: 443-445.

Black, C.A. (1965). Methods of soil analysis. Part I, American Society of Agronomy. Madison, Wisconsin, USA. 1572 p.

Chavan, K. N., Kenjale, R. Y. and Chavan, A.S. (1995). Effect of forest tree species on properties of lateritic soil. J. Ind. Soc. Soil Sci. 43: 43-46.

Dawit, S., Fritzsche, F., Takalign, M., Lehmann, J. and Zech, W. (2002). Soil organic matter composition in the subhumid Ethiopian high land as influenced by deforestation and agricultural management. Soil Sci. Soc. Am. J. 66: 68-82.

Donis, A. and Assefa, K. (2017). Characterization of physicochemical properties of soils as influenced by different land uses in Bedele area in Ilubabor Zone, Southwestern Ethiopia. J. Nat. Sci. Res. 7(5): 37-50.

Dutta, N., Dutta, S. and Karmakar, R.M. (2017). Characterization and Classification of Some Alluvium Derived Soils under Different Land Uses in Jorhat District of Assam. J. Ind. Soc. Soil Sci. 65(4): 190-198.

Dutta, S. and Zaman, A.S.N. (2013). Potassium Indexing of summer rice grown in the shallow tubewell command areas of Central Brahmaputra Valley Zone of Assam, India. Agric. Sci. Digest. 33 (4): 259-263.

McLean, E.O. (1965). Aluminium In: Methods of soil analysis. Part 2. Chemical methods. Black, C.A. (ed.). Madison, ASA, pp. 978-998.

Mhawish, Y.M. (2015). Effect of LandUse/Cover Change on physical and chemical soil properties within an Agricultural Ecosystem of Ajloun areaJordan. Intern. J. Geol. Earth Environ. Sci. 5 (2): 1-17.

Piper, C.S. (1966). Soil and plant analysis. The University of Adelaide, Australia.

Schumacher, B. A. (2002). Methods for the determination of Total Organic Carbon (TOC) in soils and sediments. United States Environmental Protection Agency Environmental Sciences Division. National Exposure Research Laboratory, P.O. Box 93478 Las Vegas.

Walkley, A. and Black, I. A. (1934). An examination of the Degtjareff method for determining soil organic matter and a proposed modification of the chromic acid titration method. Soil Sci. 37: 2938.

Wang, J., Fu, B., Qiu, Y. and Chen, L. (2001). Soil nutrients in relation to land use and landscape position in the semi-arid small catchment on the loess plateau in China. J. Arid. Environ. 48: 537-550.

\section{How to cite this article:}

Choudhury, M. R., S. Dutta and Bhattacharyya, D. 2020. Soil Properties under Different Land Use Systems in Karimganj District of Assam, India. Int.J.Curr.Microbiol.App.Sci. 9(03): 5459. doi: https://doi.org/10.20546/ijcmas.2020.903.006 